DOI: 10.34015/2523-4552.2019.1.10

Удк 343.85

Дучимінська Л. М., начальник управління контрольноперевірочної роботи головного управління Пенсійного фонду України у Волинській області

\title{
ПРИНЦИПИ ДІЯЛЬНОСТІ ПЕНСІЙНОГО ФОНДУ УКРАЇНИ ЯК СУБ’ЄКТА ЗАПОБІГАННЯ ЗЛОЧИНАМ
}

У статті розглянуто питання, що стосуються змісту принципів діяльності Пенсійного фонду України як одного із суб'єктів запобігання злочинам, з'ясовано їх сутність та зміст, а також здійснено їх класифікацію відповідно до функціональної належності.

Ключові слова: Пенсійний фонд Украӥни; запобігання; злочин; суб'єкт; принцип; класифікація; діяльність.

В статье рассмотрены вопросы, касающиеся содержания принципов деятельности Пенсионного фонда Украины как одного из субъектов профилактики преступлений, установлена их сущность и содержание, а также осуществлена их классификация в соответствии с функциональной направленностью.

Ключевые слова: Пенсионный фонд Украины; профилактика; преступление; субъект; принцип; классификация; деятельность.

Постановка проблеми. Як свідчить практика, ефективність та результативність будь-якої суспільної діяльності, включаючи запобігання злочинам, залежить від чітко визначених на нормативно-правовому рівні принципів.

У наукових джерелах слово «принцип» розглядається в різних аспектах, а саме:

1) переконання, норма, правило, яким керується хто-небудь у житті, поведінці;

2) основне вихідне положення, якої-небудь наукової системи, теорії, ідеологічного напряму; засада;

3) особливість, покладена в основу створення або здійснення чого- небудь, спосіб створення або здійснення чогось [1, с. 504].

У кримінологічній літературі принципи запобіжної діяльності класифіковані на три групи:

а) загальноправові (конституційні);

б) міжгалузеві (у цьому разі - ті, що стосуються сфери боротьби зі злочинністю);

в) галузеві, тобто ті, що відносяться до відповідної сфери суспільних відносин [2, с. 51-53].

Загалом же до принципів запобіжної діяльності науковці відносять такі: демократизму, соціальної справедливості, гуманізму, комплексності, диференціації та індивідуалізації, своє- 
часності та необхідної достатності, наукової обгрунтованості, законності та економічної доцільності [3, с. 17-18].

Саме зазначені принципи i складають сутність та зміст запобігання злочинам Пенсійним фондом України у сфері пенсійного та соціального забезпечення населення (у цій ситуації застосовуються на практиці конституційні та міжгалузеві принципи запобіжної діяльності). Водночас, як свідчить практика, важливе значення при запобіганні злочинів відіграють і принципи, які мають галузевий характер та визначені в нормативно-правових актах, що регулюють діяльність Пенсійного фонду України.

Постановка завдання. Неповнота визначеності на науковому рівні сутності цих принципів і взаємозв'язку між конституційними та міжгалузевими принципами, що має велике значення при визначенні потенційних можливостей даного суб'єкта в запобіганні злочинам, обумовила вибір теми цієї наукової статті та визначила їі головне завдання: на підставі аналізу зазначених принципів установити роль і місце Пенсійного фонду в системі запобіжної діяльності України.

Аналіз останніх досліджень i публікацій. Як засвідчили результати вивчення наукової літератури, досить активно та продуктивно розробляють проблеми, що стосуються принципів запобігання злочинам, такі вчені: О. М. Бандурка, В. С. Батиргарєєва, Є. Ю. Бараш, Ю. В. Баулін, В. І. Борисов, В. В. Василевич, В. В. Голіна, В. К. Грищук, О. М. Джужа, Т. А. Денисова, О.Г. Колб, А. В. Савченко, В. О. Туляков та ін.

Водночас у працях зазначених та інших вчених не здійснено ком- плексний аналіз галузевих принципів запобіжної діяльності Пенсійного фонду України, що й стало вирішальним при виборі предмета цього дослідження.

Виклад основного матеріалу. Діяльність Пенсійного фонду України охоплює практично всі сфери пенсійного та соціального забезпечення населення i на нормативноправовому рівні регулюється різними законами, тому принципи його функціонування можна класифікувати на такі групи:

1. Загальні, тобто ті, які визначені в усіх нормативно-правових джерелах, що стосуються роботи Пенсійного фонду України (законодавчо визначені; рівноправності; диференціації; гласності, прозорості та доступності; відповідальності) (Закони України «Про загальнообов'язкове державне пенсійне страхування» [4], «Про пенсійне забезпечення» [5], «Про збір та облік єдиного внеску на загальнообов'язкове державне соціальне страхування» [6] та ін.).

2. Спеціальні - є характерними для окремих законів (єдності умов та норм пенсійного забезпечення військовослужбовців) (Закон України «Про пенсійне забезпечення осіб, звільнених $з$ військової служби, та деяких інших осіб» [7]).

3. Конкретні - ті, які безпосередньо стосуються запобіжної діяльності (законності; доброчесності та прозорості) (Закони України «Про державну службу» [8], «Про запобігання корупції» [9]).

4. Ti, які, хоча й не визначені в законі, але витікають з його змісту (Закони України «Про державну соціальну допомогу особам з інвалідністю 3 дитинства та дітям 3 інвалідністю» 
[10], «Про статус ветеранів війни, гарантії їх соціального захисту» [11]).

Детальне вивчення зазначених та інших нормативно-правових актів, які регулюють діяльність Пенсійного фонду України, засвідчило, що кожен iз них різною мірою пов'язаний зі змістом запобігання правопорушенням і злочинам, про що, зокрема, свідчать прикінцеві положення цих джерел, у яких вказано, що за недотримання порядку та умов пенсійного та іншого соціального забезпечення різних категорій громадян настає передбачена законом юридична відповідальність.

Більш того, незважаючи на різноманітні класифікації цих принципів, здійснені на доктринальному рівні, включаючи цю роботу, слід констатувати, що на практиці їх дія має системний характер.

Показовим у цьому сенсі $\epsilon$ закріплений у Законі України «Про державну службу» принцип доброчесності (спрямованість дій державного службовця на захист публічних інтересів та відмова державного службовця від превалювання приватного інтересу під час здійснення наданих йому повноважень (пункт 5 частини першої статті 4)), який, зокрема, відображений, у Законі України «Про запобігання корупції» (наприклад, у цьому полягає реальний конфлікт інтересів - суперечність між приватним інтересом особи та їі службовими чи представницькими повноваженнями, що впливає на об'єктивність або неупередженість прийняття рішень чи на вчинення або невчинення дій під час виконання зазначених повноважень (частина перша статті 1)).

Аналогічний взаємозв'язок i взаємодія принципів простежується у змісті інших принципів, що стосу- ються діяльності Пенсійного фонду України. Так, для всіх нормативноправових актів характерним $\epsilon$ принцип законності, зміст якого визначений у частині другій статті 19 Конституції України: усі органи державної влади (у цьому контексті - Пенсійний фонд України як орган державної виконавчої влади) та їх посадові особи мають діяти у спосіб, що визначений у Конституції та законах України.

Крім того, цей принцип закріплений у пункті 6 статті 92 Основного закону, відповідно до якого виключно законами України визначаються основи соціального захисту, форми і види пенсійного забезпечення; засади регулювання праці та зайнятості, шлюбу, сім'ї, охорони дитинства, материнства, батьківства; виховання, освіти, культури і охорони здоров'я; екологічної безпеки [12].

Додаткові змістовні елементи цього принципу зазначені в інших статтях Конституції України, норми якої $\epsilon$ обов'язковими для всіх суб'єктів правозастосування, включаючи Пенсійний фонд України. Зокрема, у частині першій статті 60 Основного закону вказано, що ніхто не зобов'язаний виконувати явно злочинні розпорядження чи накази. При цьому питання законності наказу чи розпорядження законодавець закріпив у частині другій статті 41 КК України, а саме: наказ або розпорядження $\epsilon$ законними, якщо віддані відповідною особою, в належному порядку та в межах її повноважень і за змістом не суперечать чинному законодавству та не пов'язані з порушенням конституційних прав та свобод людини і громадянина [13].

Як із цього приводу зазначено в пункті 4 постанови Пленуму Верхо- 
вного Суду України від 26.12.2003 № 15 «Про судову практику у справах про перевищення влади або службових повноважень», при вирішенні питання про те, чи є вихід за межі наданих прав або повноважень явним, суди мають ураховувати, наскільки він був очевидним для службової особи і чи усвідомлювала вона протиправність своєї поведінки [14, c. 255].

Отже, у всіх випадках реалізації Пенсійним фондом України тих чи інших заходів запобіжного характеру його посадові особи мають чітко дотримуватись змісту принципу законності у своїй діяльності.

Цікавим та одночасно важливим у контексті запобігання злочинам $\epsilon$ принцип прозорості, зміст якого полягає у відкритості інформації про діяльність посадових осіб Пенсійного фонду України, крім випадків, визначених Конституцією та законами України (пункт 5 частини першої статті 4 Закону України «Про державну службу»). Поряд із цим слід зазначити, що на практиці цього принципу дотримуються не завжди, позаяк на нормативно-правовому рівні відсутні відповідні механізми з цих питань.

$\mathrm{У}$ цьому разі йдеться про те, що в жодному із законів, які регулюють діяльність Пенсійного фонду України, не закріплено його обов'язок про звіт перед громадськістю, як це, зокрема, передбачено в Законі України «Про Національну поліцію» [15]. Так, у частині першій статті 86 даного закону зазначено, що з метою інформування громадськості про діяльність поліції керівник поліції та керівники територіальних органів поліції раз на рік готують та опубліковують на офіційних вебпорталах органів поліції звіт про діяльність поліції.
Виходячи з цього, а також у зв'язку з необхідністю підвищення ролі та ефективності діяльності Пенсійного фонду України як суб'єкта запобігання злочинам, варто було б Закон України «Про загальнообов'язкове державне пенсійне страхування» доповнити статтею 103-1 «Участь громадськості у контролі за діяльністю Пенсійного фонду України» такого змісту:

«Для забезпечення прозорості діяльності Пенсійного фонду України та його територіальних структурних підрозділів зазначені державні органи один раз на рік готують звіт про діяльність з питань пенсійного та соціального забезпечення населення та публікують його на своїх офіційних вебпорталах з дотриманням вимог закону щодо нерозголошення конфіденційної інформації та персональних даних про особу.

Керівники Пенсійного фонду України та його територіальних органів зобов'язані регулярно оприлюднювати статистичні й аналітичні дані про вжиті заходи щодо виявлення, запобігання та припинення порушень у сфері пенсійного та соціального забезпечення на офіційних вебпорталах органів, які вони очолюють».

I, зрештою, ще одним системним та надзвичайно важливим принципом у запобіжній діяльності Пенсійного фонду України є принцип верховенства права. Його зміст визначено в статті 8 Основного закону, а саме: Конституція України має найвищу юридичну силу. Закони та інші нормативно-правові акти приймаються на основі Конституції України і повинні відповідати їй.

Як у зв'язку з цим зазначено у пункті 1 постанови Пленуму Верхов- 
ного Суду України від 01.11.1996 № 9 «Про застосування Конституції України при здійсненні правосуддя», відповідно до статті 8 Конституції України визнається і діє принцип верховенства права. Конституційні права та свободи людини і громадянина $\epsilon$ безпосередньо діючими. Вони визначають цілі і зміст законів та інших нормативно-правових актів, зміст i спрямованість діяльності органів законодавчої та виконавчої влади, органів місцевого самоврядування i забезпечуються захистом правосуддя [16, с. 136].

Як засвідчило вивчення змісту інших принципів, що ввійшли до переліку класифікаційних груп, виведених у цій роботі, вони також мають системний характер і забезпечують діяльність Пенсійного фонду як суб'єкта запобігання злочинам. При цьому слід констатувати, що зазначений державний орган, хоча i не належить до спеціалізованих суб'єктів запобіжної діяльності (як Національна поліція, прокуратура, Служба безпеки України та ін.), але зобов'язаний дотримуватися при запобіганні злочинам принципів, що визначені на законодавчому рівні.

Висновки. Таким чином, 3'ясування змісту принципів запобіжної діяльності важливе не так з точки зору наукового пізнання, як 3 погляду їх практичної значущості в роботі будь-якого суб'єкта запобігання злочинам, незалежно від його функціонального призначення $\mathrm{y}$ сфері боротьби зі злочинністю.

\section{Список використаних джерел}

1. Великий тлумачний словник української мови. Упоряд. Т. В. Ковальова. Харків : Фоліо, 2005. 767 с.

2. Кримінологія: Навч. посіб. / О. М. Джужа, В. В. Василевич, О. Г. Колб та ін.; за заг. ред. д.ю.н., проф. О. М. Джужі. Київ : Атіка, 2009. 312 с.

3. Профілактика злочинів: Підручник / О. М. Джужа, В. В. Василевич, О. Ф. Гіда та ін.; за заг. ред. д.ю.н., проф. О. М. Джужі. Київ : Атіка, 2011. 720 с.

4. Про загальнообов'язкове державне пенсійне страхування. Закон України від 09 липня 2003 року № 1058-IV (зі змінами). Відомості Верховної Ради України. 2018. № 38. Ст. 280.

5. Про пенсійне забезпечення: Закон України (зі змінами) від 05 листопада 1991 року № 1788-XII. Відомості Верховної Ради України. 2018. № 20. Ст. 189.

6. Про збір та облік єдиного внеску на загальнообов'язкове державне соціальне страхування: Закон України (зі змінами) від 08 липня 2010 року № 2464-VI. Відомості Верховної Ради України. 2011. № 2-3. Ст. 11.

7. Про пенсійне забезпечення осіб, звільнених з військової служби, та деяких інших осіб: Закон України від 09 квітня 1992 року № 2262-XII. Відомості Верховної Ради України. № 29. Ст. 399.

8. Про державну службу: Закон України від 10 грудня 2015 року № 889-VIII. Biдомості Верховної Ради України. № 4. Ст. 43.

9. Про запобігання корупції: Закон України від 14 жовтня 2014 року. Режим доступу: URL: http://zakon0.rada.gov.ua/ laws/show/1700-18 (дата звернення: 25.04.2019).

10. Про державну соціальну допомогу особам з інвалідністю з дитинства та дітям $з$ інвалідністю: Закон України від 16 листопада 2000 року № 2109-III. Відомості Верховної Ради України. № 1. Ст. 2. 
11. Про статус ветеранів війни, гарантії їх соціального захисту: Закон України від 22 жовтня 1993 року № 3551-XII. Відомості Верховної Ради Украӥни. № 45. Ст. 425.

12. Конституція України : прийнята 28 червня 1996 року. Відомості Верховної Ради України. 1996. № 30. Ст. 141.

13. Кримінальний кодекс України: Закон України від 05 квітня 2001 року № 2341-III. Відомості Верховної Ради України. № 25. Ст. 131.

14. Про судову практику у справах про перевищення влади або службових повноважень. Постанова Пленуму Верховного Суду України від 26.12.2003 № 15. URL: https://zakon.rada.gov.ua/laws/show/v0015700-03 (дата звернення: 25.04.2019).

15. Про національну поліцію України : Закон України від 02 липня 2015 року № 580-VIII. Відомості Верховної Ради України. 2015. № 40/41. С. 379.

16. Про застосування Конституції України при здійсненні правосуддя. Постанова Пленуму Верховного Суду України від 01.11.1996 № 9. URL: https://zakon.rada.gov.ua/laws/show/v0009700-96 (дата звернення: 25.04.2019).

\section{References}

1. Velikij tlumachnij slovnik ukrayinskoyi movi (2005). Uporyad. T. V. Kovalova. Harkiv: Folio [in Ukrainian].

2. Dzhuzha, O. M., Vasilevich, V. V., Kolb, O. G. (2009). Kriminologiya: navch. posib. Kiyiv: Atika [in Ukrainian].

3. Dzhuzha, O. M., Vasilevich, V. V., Gida, O. F. (2011). Profilaktika zlochiniv: pidruchnik. Kiyiv: Atika [in Ukrainian].

4. Pro zagalnoobov'yazkove derzhavne pensijne strahuvannya. Zakon Ukrayini vid 09 lipnya 2003 roku N 1058-IV (zi zminami). Vidomosti Verhovnoyi Radi Ukrayini. 2018. N 38. St. 280 [in Ukrainian].

5. Pro pensijne zabezpechennya: Zakon Ukrayini (zi zminami) vid 05 listopada 1991 roku N 1788-XII. Vidomosti Verhovnoyi Radi Ukrayini. 2018. N 20. St. 189 [in Ukrainian].

6. Pro zbir ta oblik yedinogo vnesku na zagalnoobov'yazkove derzhavne socialne strahuvannya: Zakon Ukrayini (zi zminami) vid 08 lipnya 2010 roku N 2464-VI. Vidomosti Verhovnoyi Radi Ukrayini. 2011. N 2-3. St. 11 [in Ukrainian].

7. Pro pensijne zabezpechennya osib, zvilnenih z vijskovoyi sluzhbi, ta deyakih inshih osib: Zakon Ukrayini vid 09 kvitnya 1992 roku N 2262-HII. Vidomosti Verhovnoyi Radi Ukrayini. N 29. St. 399 [in Ukrainian].

8. Pro derzhavnu sluzhbu: Zakon Ukrayini vid 10 grudnya 2015 roku N 889-VIII. Vidomosti Verhovnoyi Radi Ukrayini. N 4. St. 43 [in Ukrainian].

9. Pro zapobigannya korupciyi: Zakon Ukrayini vid 14 zhovtnya 2014 roku. URL: http://zakon0.rada.gov.ua/ laws/show/1700-18 (data zvernennya: 25.04.2019) [in Ukrainian].

10. Pro derzhavnu socialnu dopomogu osobam $\mathrm{z}$ invalidnistyu $\mathrm{z}$ ditinstva ta dityam z invalidnistyu: Zakon Ukrayini vid 16 listopada 2000 roku N 2109-III. Vidomosti Verhovnoyi Radi Ukrayini. N 1. St. 2 [in Ukrainian].

11. Pro status veteraniv vijni, garantiyi yih socialnogo zahistu: Zakon Ukrayini vid 22 zhovtnya 1993 roku N 3551-HII. Vidomosti Verhovnoyi Radi Ukrayini. N 45. St. 425 [in Ukrainian].

12. Konstituciya Ukrayini : prijnyata 28 chervnya 1996 roku. Vidomosti Verhovnoyi Radi Ukrayini. 1996. N 30. St. 141 [in Ukrainian].

13. Kriminalnij kodeks Ukrayini: Zakon Ukrayini vid 05 kvitnya 2001 roku N 2341III. Vidomosti Verhovnoyi Radi Ukrayini. N 25. St. 131 [in Ukrainian].

14. Pro sudovu praktiku u spravah pro perevishennya vladi abo sluzhbovih povnovazhen. Postanova Plenumu Verhovnogo Sudu Ukrayini vid 26.12.2003 N 15. URL: 
https://zakon.rada.gov.ua/laws/show/v0015700-03 (data zvernennya: 25.04.2019) [in Ukrainian].

15. Pro nacionalnu policiyu Ukrayini : Zakon Ukrayini vid 02 lipnya 2015 roku N 580-VIII. Vidomosti Verhovnoyi Radi Ukrayini. 2015. N 40/41. S. 379 [in Ukrainian].

16. Pro zastosuvannya Konstituciyi Ukrayini pri zdijsnenni pravosuddya. Postanova Plenumu Verhovnogo Sudu Ukrayini vid 01.11.1996 N 9. URL: https://zakon.rada.gov.ua/ laws/show/v0009700-96 (data zvernennya: 25.04.2019) [in Ukrainian].

L. Duchiminska, Head of the Volyn region Control and Check Department of the Pension Fund of Ukraine

\section{Activities principles of the Pension Fund of Ukraine as the crime prevention subject}

The article deals with issues related to the content of the activities principles of the Pension Fund of Ukraine as one of the crime prevention subjects. Their essence and content is cleared up. Their classification according to their functional affiliation was made.

The principles of the prevention activities include the following: democracy; social justice; humanism; complexity; differentiation and individualization; timeliness and necessary sufficiency; scientific substantiation; legality and economic feasibility. Those principles form the essence and content of the crime prevention by the Pension Fund of Ukraine in the sphere of pensions and social security of the population (in this situation, the constitutional and inter-sectoral principles of preventive activities are applied in practice). As the practice shows, the principles of the sectoral nature are defined in the normative and legal acts, which regulate the activity of the Pension Fund of Ukraine, and play the important role in crime preventing.

The detailed study of the relevant normative and legal acts, which regulate the activity of the Pension Fund of Ukraine, shows that each of them, in any way, is related to the content of crime prevention, as it is evidenced, in particular, by the final provisions of those sources, which indicate that for non-compliance with the procedure and conditions of the pension and other social security of different categories of citizens, legal liability stipulated by law comes.

Thus, the clarification of the content of the principles of preventive activities is important not only and not so much from the point of view of scientific knowledge, but in terms of their practical significance in the work of any subject of crime prevention, regardless of its functional purpose in the sphere of combating crime.

Keywords: Pension Fund of Ukraine; prevention; crime; subject; principle; classification; activity.

Надійшла до редакції 03.05.2019 